\title{
Pre-Clinical Investigations of Verbena officinalis L. Tisane Effects against Induced Stress in Wistar Male Rats ${ }^{\dagger}$
}

\author{
Sonia M. Oliveira ${ }^{1,2, *(\mathbb{D})}$, Elsa Dias ${ }^{1,3}$ and Maria de Lourdes Pereira ${ }^{1,4}$ (D) \\ 1 CICECO_-Aveiro Institute of Materials, 3810-193 Aveiro, Portugal; elsadias@ua.pt (E.D.); \\ mlourdespereira@ua.pt (M.d.L.P.) \\ 2 Hunter Medical Research Institute, Newcastle, NSW 2305, Australia \\ 3 Centro Hospitalar do Baixo Vouga, 3810-193 Aveiro, Portugal \\ 4 Department of Medical Sciences, University of Aveiro, 3810-193 Aveiro, Portugal \\ * Correspondence: sonia.oliveira@ua.pt \\ + Presented at the 1st International E-Conference on Antioxidants in Health and Disease, 1-15 December 2020; \\ Available online: https://cahd2020.sciforum.net/.
}

check for

updates

Citation: Oliveira, S.M.; Dias, E.; Pereira, M.d.L. Pre-Clinical Investigations of Verbena officinalis L. Tisane Effects against Induced Stress in Wistar Male Rats. Med. Sci. Forum 2021, 2, 24. https://doi.org/10.3390/ CAHD2020-08864

Academic Editor: Mihalis I

Panagiotidis

Published: 30 November 2020

Publisher's Note: MDPI stays neutral with regard to jurisdictional claims in published maps and institutional affiliations.

Copyright: (c) 2020 by the authors. Licensee MDPI, Basel, Switzerland. This article is an open access article distributed under the terms and conditions of the Creative Commons Attribution (CC BY) license (https:// creativecommons.org/licenses/by/ $4.0 /)$.
Abstract: Verbena officinalis or vervain is globally used as an herbal medicine and dietary supplement for anti-depressive and anti-convulsive purposes, as well as to treat inflammatory disorders, skin burns, abrasions and gastric problems. In our exploratory research, we investigated the biochemical, antioxidant and histopathological effects of local $V$. officinalis infusion in rats previously submitted to chronic physical stress. The animals presented significant alterations in several organs' ratios; namely the epididymis and brain ratios with $p=0.003$ and $p=0.013$, respectively. Moreover, tissues such as those of the kidney and liver presented relevant histologic alterations due to experimental conditions. Total protein, creatine kinase (CKI), uric acid (URCA), circulating and hepatic alkaline phosphatase (ALP) and Glutathione S-transferases (GSTs) and glucose levels were statistically different between treated and non-treated animals with $p<0.05$. Altogether, biochemical and haematological results indicated significant impacts in antioxidant, lipidic and protein metabolism. Therefore, physical stress and vervain infusion have significant in vivo effects. Chronic stress effects were not counteracted by vervain consumption (e.g., $p=0.5$ for hepatic and renal superoxide dismutase (SOD) levels between the different groups). A correlation between histology and the active components in an herbal extract would enable a better evaluation of herbal medicines. Accordingly, further studies of vervain extracts effects are in progress.

Keywords: Verbena officinalis; oxidative stress; male reproductive morphology; toxicology; ethnopharmacology

Supplementary Materials: The following are available online at https:/ /www.mdpi.com/article/10 .3390/CAHD2020-08864/s1.

Institutional Review Board Statement: This study was conducted in agreement with the institutional and international guidelines for ethics in animal experiments (Rule no. 86/609/CEE$24 / 11 / 92)$

Informed Consent Statement: Not applicable.

Data Availability Statement: Data available on request. 